\title{
Ro 13-9904: AFFINITY FOR PENICILLIN BINDING PROTEINS AND EFFECT ON CELL WALL SYNTHESIS
}

\author{
R. B. Wright, S. D. Makover and E. Telep \\ Departments of Microbiology and Immunotherapy, Hoffmann-La Roche Inc., \\ Nutley, N. J. 07110, U.S.A.
}

(Received for publication January 29, 1981)

\begin{abstract}
Studies on the binding of Ro 13-9904, a new broad-spectrum cephalosporin, showed that it had higher affinities for PBPs $1 \mathrm{~b}, 2$, and 3 of Escherichia coli $(3>1 \mathrm{~b}>2)$ than cefazolin, cephaloridine, cephalothin or cephalexin. With Haemophilus influenzae, Ro 13-9904 showed highest affinities for PBPs 4 and 5 followed by PBP 2. It inhibited total cell wall synthesis at lower concentrations than the other $\beta$-lactam antibiotics tested.
\end{abstract}

Recent investigations have compared the in vitro activities of several third generation $\beta$-lactam antibiotics including Ro 13-9904 (Fig. 1), a semisynthetic cephalosporin, against Gram-negative bacteria $^{1 \sim 3)}$. We studied the mechanism of action of Ro 13-9904 from the viewpoint of affinity to penicillin-binding proteins (PBPs), morphological changes and inhibition of peptidoFig. 1. Chemical structure of Ro 13-9904. glycan synthesis.

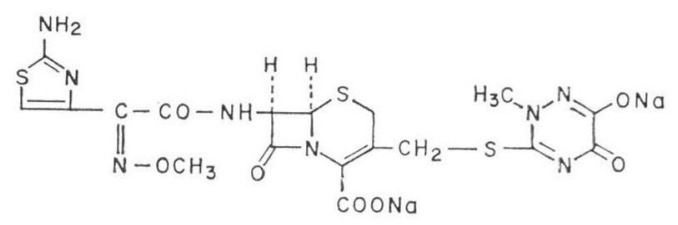

\section{Materials and Methods}

Antibiotics, Labelled Compounds and Other Chemicals

The antibiotics used in this study included Ro 13-9904 (Hoffmann-La Roche, Nutley, N.J., U.S.A.); cefazolin, cephalexin, cephaloridine and cephalothin (Eli Lilly Co., Indianapolis, IN, U.S.A.); and penicillin G (pen G; Sigma, St. Louis, MO, U.S.A.). Radioactive compounds included $\left[{ }^{14} \mathrm{C}\right]$-pen G, specific activity of $50 \sim 60 \mathrm{mCi} / \mathrm{mmol}$ and UDP-N-acetyl-[ $\left.{ }^{14} \mathrm{C}\right]$-glucosamine, specific activity $323 \mathrm{mCi} / \mathrm{mmol}$ (Amersham Corp., Arlington Heights, IL, U.S.A.); and diamino $\left[{ }^{14} \mathrm{C}\right]$-pimelic acid (New England Nuclear, Boston, MA, U.S.A.), specific activity $105.26 \mathrm{mCi} / \mathrm{mmol}$. Reagents for sodium dodecylpolyacrylamide gel electrophoresis were from Bio-Rad Laboratories (Richmond, CA, U.S.A.). All other chemicals were of reagent grade.

Bacterial Strains

Strains used included Haemophilus influenzae (ATCC 19418); Escherichia coli K12 strain KN126 (a gift from B. G. SpRATT); Bacillus cereus strain T (QMB 1590); E. coli Y-10, thr-1, leu B6, thi-1, ribf D1, sup E 44 (a gift from B. BACHMAnN); E. coli K12 JE5707, Dap- ${ }^{-}$Lys $^{-}$, Thi- (a gift from Y. Hirota).

Binding of $\beta$-Lactam Antibiotics to the PBPs of E. coli and H. influenzae

Preparations of membranes and assay of PBPs of E. coli were performed according to the procedure reported by SPRATT ${ }^{4)}$. A modification of that procedure, which was used to determine binding to $H$. influenzae PBPs, has been described recently ${ }^{5)}$. The modified gel system, which separates PBPs 1a and 1b of $E$. coli ${ }^{\theta)}$, was used for the separation of the PBPs of E. coli and H. influenzae. Levels of $\left[{ }^{14} \mathrm{C}\right]$-penicillin $\mathrm{G}$ bound to PBPs were quantitated by densitometry of fluorograms (Zeiss PMQ II thin-layer chromatogram spectrophotometer coupled to a Columbia Scientific Industries CSI-38 integrator). Binding affinities are expressed in terms of $I_{50}$ values, which are the concentrations $(\mu \mathrm{g} / \mathrm{ml})$ required to inhibit the 
binding of $\left[{ }^{14} \mathrm{C}\right]$-penicillin $\mathrm{G}$ by $50 \%$.

\section{Morphological Studies}

To determine effects on morphology, exponentially growing $H$. influenzae cells ( $5 \mathrm{ml}$; approx. $1 \times$ $10^{\circ} \mathrm{cells} / \mathrm{ml}$ ) were further incubated after the addition of Ro 13-9904. At specified times, samples were removed and examined by phase-contrast microscopy.

Measurement of Inhibition of Peptidoglycan Synthesis

Incorporation of $\left[{ }^{14} \mathrm{C}\right]-$ meso-diaminopimelic acid (DAP) into the cell wall of $E$. coli K12 JE5707 was measured according to NozAKI et al. ${ }^{7)}$ with slight modifications. A synthetic medium $\left(1 \mathrm{~g}\left(\mathrm{NH}_{4}\right)_{2}\right.$ $\mathrm{SO}_{4}, 10.5 \mathrm{~g} \mathrm{~K}_{2} \mathrm{HPO}_{4}, 4.5 \mathrm{~g} \mathrm{KH}_{2} \mathrm{PO}_{4}, 0.1 \mathrm{~g} \mathrm{MgSO}_{4}$ per liter supplemented with $0.5 \%$ glucose, $10 \mu \mathrm{g} / \mathrm{ml}$ DAP, $200 \mu \mathrm{g} / \mathrm{ml}$ lysine and $0.5 \mu \mathrm{g} / \mathrm{ml}$ thiamine), which allowed a doubling time of 60 minutes, was used. After 2 hours at $37^{\circ} \mathrm{C} 0.5 \mathrm{ml}$ samples (containing $0.25 \mu \mathrm{Ci}\left[{ }^{14} \mathrm{C}\right]$-DAP) were processed.

Measurement of Inhibition of Peptidoglycan Transpeptidase

The procedure of MOORE et al. ${ }^{8)}$ was used to assay peptidoglycan transpeptidase activity of ether treated $E$. coli K12 Y-10 (ETB). Uridine 5'-diphospho-N-acetyl-muramyl-L-alanyl-D-glutamyl-mesodiaminopimelyl-D-alanyl-D-alanine (UDP-Mur-NAc-pentapeptide) was isolated from B. cereus strain $\mathrm{T}^{8)}$. The concentration of pentapeptide was determined by ultraviolet adsorption at $262 \mathrm{~nm}$ relative to a uridine diphosphate (UDP) standard. An analysis of UDP-Mur-NAc-pentapeptide resulted in a ratio of alanine: glutamic acid: meso-DAP of $2.7: 1: 1.1$, which is consistent with the theoretical value of 3 : $1: 1$.

\section{Results}

\section{Affinity of Ro 13-9904 to PBPs of E. coli and H. influenzae}

The affinities to PBPs were estimated in two ways: by measuring the competition of unlabelled Ro 13-9904 with $\left[{ }^{14} \mathrm{C}\right]$-pen $\mathrm{G}$ for binding to PBPs and by measuring the direct binding of $\left[{ }^{14} \mathrm{C}\right]$-Ro $13-9904$ to PBPs. Profiles of competition of unlabelled Ro 13-9904 and other cephalosporin derivatives with $\left[{ }^{14} \mathrm{C}\right]$-pen $\mathrm{G}$ for binding to PBPs in E. coli and in H. influenzae are shown respectively in Figs. 2 and 3.

All the cephalosporins tested showed high affinity for PBP 1a of E. coli. Ro 13-9904 generally showed higher affinities for PBPs 1 b, 2 and 3 than those of the reference cephalosporins (Table 1). With H. influenzae, Ro 13-9904 showed highest affinities for PBPs 4 and 5 (Table 2), whereas the other cephalosporins all showed highest affinity for PBP 2.

The binding of $\left[{ }^{14} \mathrm{C}\right]-$ Ro $13-9904$ to the PBPs of E. coli is shown in Fig. 4. We were unable to quantitate by densitometry the level of binding due to high background. Nevertheless, when bound

Table 1. Competition of $\beta$-lactam antibiotics for $\left[{ }^{14} \mathrm{C}\right]$-pen $\mathrm{G}$ binding to E. coli K12 KN126 PBPs.

\begin{tabular}{l|c|c|c|c|c|c|c}
\hline \multirow{2}{*}{ Antibiotic } & \multirow{2}{*}{$\begin{array}{c}\mathrm{MIC}^{1} \\
(\mu \mathrm{g} / \mathrm{ml})\end{array}$} & \multicolumn{7}{|c}{$\mathrm{I}_{50}$ for PBPs $(\mu \mathrm{g} / \mathrm{ml})$} \\
\cline { 3 - 8 } & & $1 \mathrm{a}$ & $1 \mathrm{~b}$ & 2 & 3 & 4 & $5 / 6$ \\
\hline Ro 13-9904 & 0.125 & $<0.1$ & 1.8 & 3.6 & $<0.1$ & $>78$ & $>78$ \\
Cefazolin & 6.25 & $<1$ & 17 & 7.5 & 9 & 11 & $>31$ \\
Cephaloridine & 12.5 & $<1$ & 8 & 130 & 13 & 15 & $>62.5$ \\
Cephalothin & 12.5 & N.D. & $>100$ & 90 & 7.6 & 70 & $>62.5$ \\
Cephalexin & 25.0 & N.D. & N.D. ${ }^{3}$ & N.D. & N.D. & N.D. & N.D. \\
\hline
\end{tabular}

1 MIC is defined as the lowest concentration which still gives a zone of inhibition by the agar diffusion well technique.

2 Not determined.

3 Although $I_{50 \text { 's }}$ for cephalexin were not calculated, it is apparent from Fig. 2 that the $I_{50}$ for PBP $1 \mathrm{~b}$ is $>125$. 
Fig. 2. Binding of $\left[{ }^{14} \mathrm{C}\right]$-pen $\mathrm{G}$ to the PBPs of E. coli $\mathrm{K} 12 \mathrm{KN} 126$.

Each lane represents a reaction containing $0.076 \mu \mathrm{mole} / \mathrm{ml}\left[{ }^{14} \mathrm{C}\right]$-pen $\mathrm{G}(59.5 \mu \mathrm{Ci} / \mu \mathrm{mole})$ plus the following concentrations $(\mu \mathrm{g} / \mathrm{ml})$ of unlabelled cephalosporin derivatives: Ro 13-9904; $\mathrm{A}=0, \mathrm{~B} \sim \mathrm{F}=$ $0.125,0.615,3.125,15.625,78.12$, respectively; cefazolin, $\mathrm{G} \sim \mathrm{I}=1.25,6.25,31.3$, respectively; cephaloridine, $\mathrm{J} \sim \mathrm{L}=2.5,12.5,62.5$, respectively; cephalothin, $\mathrm{M} \sim \mathrm{O}=2.5,12.5,62.5$, respectively; and cephalexin, $\mathrm{P}, \mathrm{Q}=25,125$, respectively.

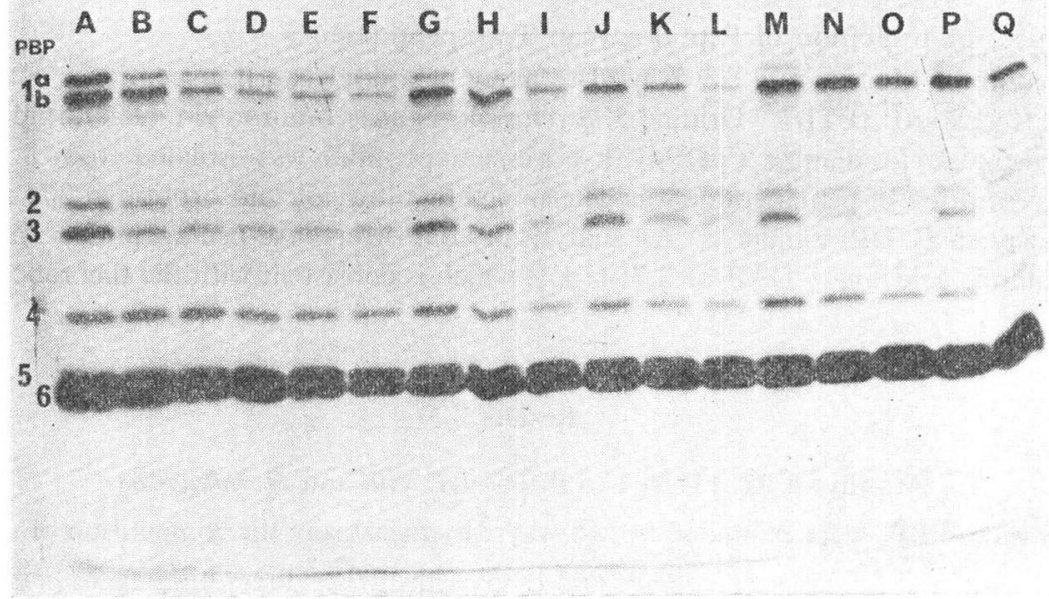

Fig. 3. Binding of $\left[{ }^{14} \mathrm{C}\right]$-pen $\mathrm{G}$ to the PBPs of $H$. influenzae.

Each lane represents a reaction containing $0.14 \mu \mathrm{mole} / \mathrm{ml}\left[{ }^{14} \mathrm{C}\right]$-pen $\mathrm{G}(59.5 \mu \mathrm{Ci} / \mu \mathrm{mole})$ plus the following concentrations $(\mu \mathrm{g} / \mathrm{ml})$ of unlabelled cephalosporin derivatives: Ro 13-9904; $\mathrm{A}=0, \mathrm{~B} \sim \mathrm{F}=$ $0.01,0.05,0.25,1.25,6.25$, respectively; cefazolin, $\mathrm{G} \sim \mathrm{I}=0.31,1.6,7.8$, respectively; cephaloridine, $\mathrm{J} \sim$ $\mathrm{L}=0.04,0.19,0.95$, respectively; and cephalexin, $\mathrm{P}, \mathrm{Q}=12.5,62.5$, respectively.

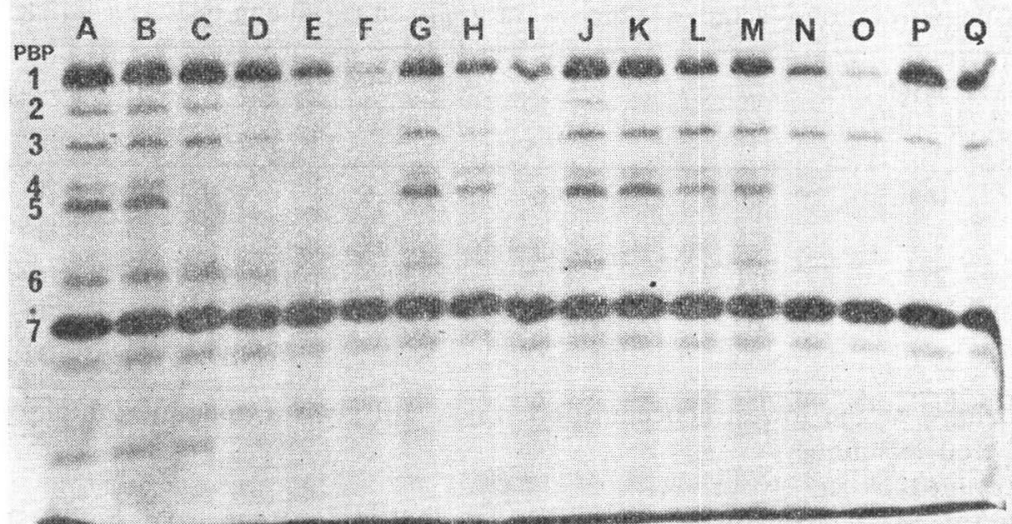


Table 2. Competition of $\beta$-lactam antibiotics for $\left[{ }^{14} \mathrm{C}\right]$-pen $\mathrm{G}$ binding to $H$. influenzae PBPs.

\begin{tabular}{l|c|c|c|c|c|c|c|c}
\hline \multirow{2}{*}{ Antibiotic } & \multirow{2}{*}{$\begin{array}{c}\mathrm{MIC} \\
(\mu \mathrm{g} / \mathrm{ml})\end{array}$} & \multicolumn{7}{|c}{$\mathrm{I}_{50}$ for PBPs $(\mu \mathrm{g} / \mathrm{ml})$} \\
\cline { 3 - 8 } & 1 & 2 & 3 & 4 & 5 & 6 & 7 \\
\hline Ro 13-9904 & 0.06 & 1.2 & 0.15 & 0.6 & 0.017 & 0.038 & 1 & $>6.25$ \\
Cefazolin & 1.57 & $<1.6$ & $<0.15$ & 1.4 & 1.7 & 2.7 & N.D. & $>7.8$ \\
Cephaloridine & 0.19 & $>0.95$ & 0.1 & $>0.95$ & $>0.95$ & $>0.95$ & 0.85 & $>0.95$ \\
Cephalothin & 0.79 & 0.75 & $<0.16$ & $>1.95$ & N.D. & N.D. & N.D. & $>1.95$ \\
Cephalexin & 12.5 & N.D. & N.D. & N.D. & N.D. & N.D. & N.D. & N.D. \\
\hline
\end{tabular}

Fig. 4. Binding of $\left[{ }^{14} \mathrm{C}\right]-\mathrm{Ro} 13-9904$ to $E$. coli membrane fraction.

Each lane represents a reaction containing 0.09 $\mu \mathrm{mole} / \mathrm{ml}\left[{ }^{14} \mathrm{C}\right]-\mathrm{Ro} 13-9904(48.2 \mu \mathrm{Ci} / \mu$ mole $)$ plus the following concentrations $(\mu \mathrm{g} / \mathrm{ml})$ of unlabelled penicillin $\mathrm{G}: \mathrm{A}=0, \mathrm{~B}=0.5, \mathrm{C}=2.5, \mathrm{D}=12.5$, $\mathrm{E}=62.4, \mathrm{~F}=312$. Lane $\mathrm{G}$ represents a reaction containing $0.09 \mu \mathrm{mole} / \mathrm{ml}\left[{ }^{14} \mathrm{C}\right]$-penicillin $\mathrm{G}$ (48.2 $\mu \mathrm{Ci} / \mu$ mole) plus $\mathrm{H}_{2} \mathrm{O}$.

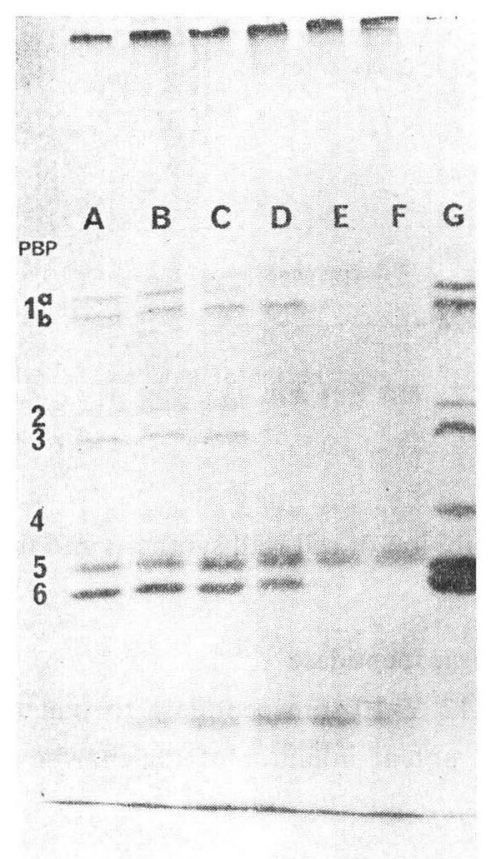

3. Inhibition of Peptidoglycan Synthesis

The inhibitory effect of Ro 13-9904 and other $\beta$-lactam antibiotics on the incorporation of $\left[{ }^{14} \mathrm{C}\right]-$ meso-diaminopimelic acid (DAP) into the cell wall of E. coli K12 JE5707 is shown in Fig. 5. Ro 13-9904 inhibited cell wall synthesis at concentrations considerably lower than were required for several other cephalosporins and for pen directly, [ $\left.{ }^{14} \mathrm{C}\right]-\mathrm{Ro}$ 13-9904 showed affinity for the same 6 PBPs as shown with $\left[{ }^{14} \mathrm{C}\right]$-pen $\mathrm{G}$ binding, although differences were observed in the relative distribution of label. In the case of $H$. influenzae (not shown), additional bands which did not compete with unlabelled pen $\mathrm{G}$ were detected. These may be artifacts for which we do not presently have an explanation.

\section{Morphological Changes Induced in H. influenzae by Ro 13-9904}

The morphological effects of some penicillins, cephalosporins and an amidino-penicillin on growing $H$. influenzae cells were previously reported $^{5)}$. In this study (data not shown) Ro 13-9904 produced slightly elongated cells after 30 minutes at a concentration as low as 0.005 $\mu \mathrm{g} / \mathrm{ml}$, whereas at 0.5 and $1 \mu \mathrm{g} / \mathrm{ml}$ cells with bulges appeared. Exposure to $1 \mu \mathrm{g} / \mathrm{ml}$ for 90 minutes resulted in spheroplasts and lysed cells. Upon prolonged incubation ( 5 hours) the cells exposed to $0.005 \mu \mathrm{g} / \mathrm{ml}$ Ro 13-9904 were 2 3 times longer than normal, and were $10 \sim 15$ times longer at 0.05 and $0.1 \mu \mathrm{g} / \mathrm{ml}$ respectively.

Table 3. Inhibition of peptidoglycan synthesis in $E$. coli $\mathrm{K} 12 \mathrm{JE} 5707$.

\begin{tabular}{l|r|c}
\hline \multicolumn{1}{c|}{ Antibiotic } & $\begin{array}{c}\text { MIC } \\
(\mu \mathrm{g} / \mathrm{ml})\end{array}$ & $\begin{array}{c}\text { Conc. required for 50\% } \\
\text { inhibition of }\left[{ }^{14} \mathrm{C}\right]-\mathrm{DAP} \\
\text { incorporation }(\mu \mathrm{g} / \mathrm{ml})\end{array}$ \\
\hline Ro 13-9904 & 0.2 & 0.3 \\
Cefazolin & 6.3 & 1.8 \\
Cephaloridine & 12.5 & 2.6 \\
Cephalothin & 6.3 & 13.5 \\
Cephalexin & 25.0 & $>100.0$ \\
Penicillin G & 50.0 & 12.5 \\
\hline
\end{tabular}


Fig. 5. Inhibition of peptidoglycan synthesis in $E$. coli K12 JE5707 by cephalosporins and pen G.

The amount of DAP incorporated in the control incubation mixture was $0.35 \mathrm{nmol}$. (See Table 3 for comparison of MIC values and concentration required for $50 \%$ inhibition of $\left[{ }^{14} \mathrm{C}\right]$-DAP incorporation).

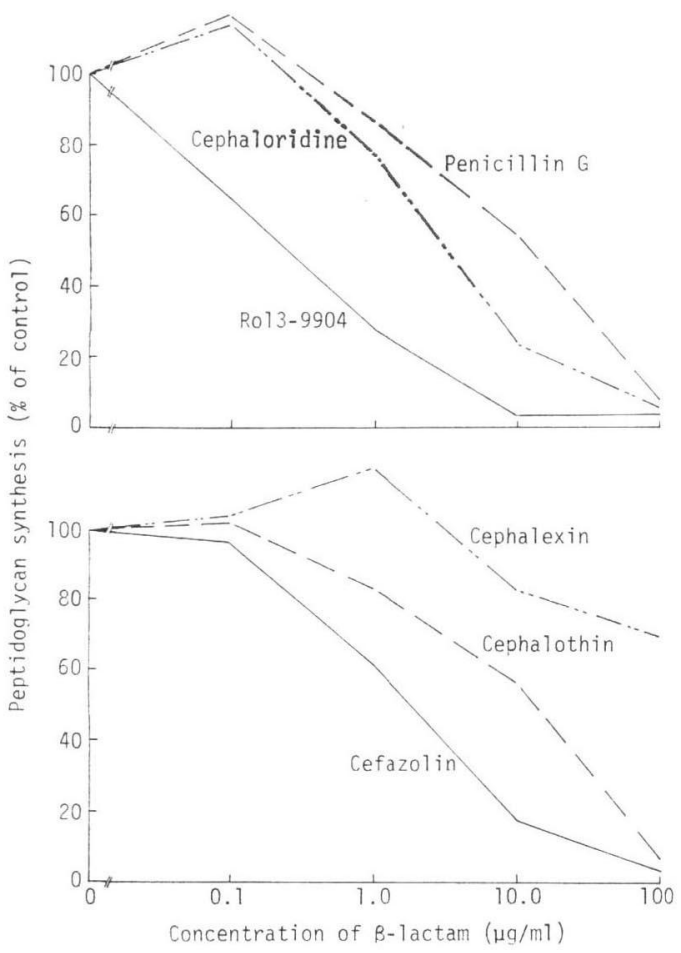

Fig. 6. Inhibition of transpeptidase activity by Ro 13-9904 and other cephalosporins in ETB of E. coli $\mathrm{K} 12 \mathrm{Y}-10$.

The percent incorporation of $\mathrm{N}$-acetyl- $\left[{ }^{14} \mathrm{C}\right]$ glucosamine at a range of antibiotic concentrations relative to the control reaction ${ }^{8}$ ) is shown.

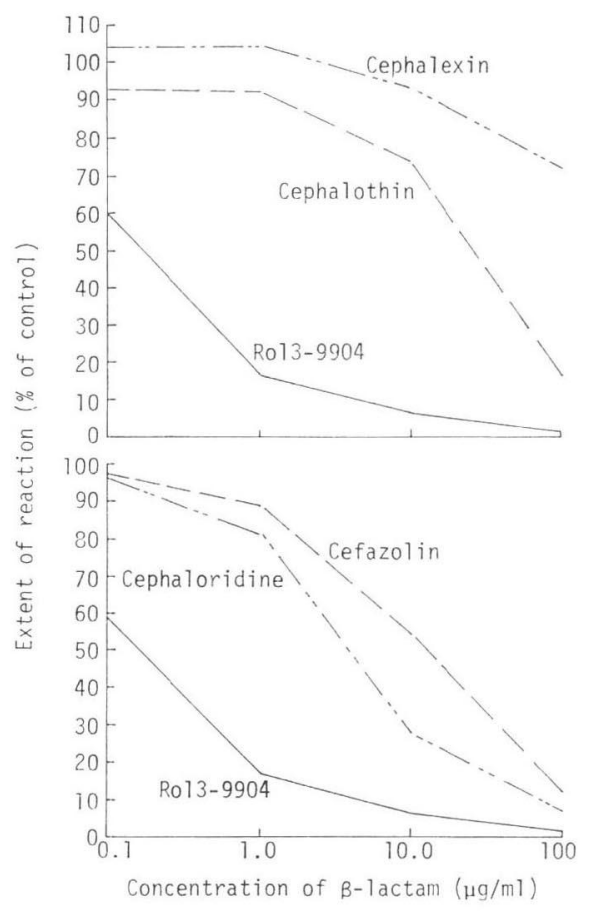

G. A comparison of the concentrations required for $50 \%$ inhibition of cell wall synthesis and the MICs for each of the $\beta$-lactams is shown in Table 3.

\section{Inhibition of Peptidoglycan Transpeptidase}

A comparison of the effect of Ro 13-9904 on E. coli K12 Y-10 transpeptidase to that of other cephalosporins is shown in Fig. 6. Ro 13-9904 is a more potent inhibitor of the enzyme than the other compounds tested.

\section{Discussion}

Our studies compared a few biochemical activities of Ro 13-9004 to those of several other $\beta$-lactam antibiotics and found it to be the most potent of those tested. Results of binding experiments revealed that it had higher affinity for PBPs $1 \mathrm{~b}, 2$ and 3 of E. coli $(3>1 \mathrm{~b}>2)$ than the other cephalosporins tested (Table 1). With $H$. influenzae, Ro 13-9904 differs from the other $\beta$-lactam antibiotics tested in that it has the highest affinity for PBPs 4 and 5 rather than PBP $2^{5)}$ (Table 2). The affinity of Ro 13-9904 for PBPs 4 and 5 is 9 and 4 times higher, respectively, than the affinity for PBP 2. It should be noted that the $I_{50}$ of Ro 13-9904 for PBP 2 is similar to that of the reference cephalosporins. The high affinity for PBPs 4 and 5, may suggest that the mode of action of Ro 13-9904 against $H$. influenzae is different from that of other cephalosporins or other $\beta$-lactam antibiotics ${ }^{5}$. 
As with other $\beta$-lactam antibiotics which show high affinity for PBP 3 of E. coli ${ }^{9}$, Ro 13-9904 causes filamentation of cells over a range of $1 / 4$ to $4 \times$ MIC (personal communication, Dr. M. J. KRAMER). Our studies show that it also causes filamentation of $H$. influenzae cells.

Ro 13-9904 proved to be the most potent inhibitor of total cell wall synthesis (Table 3) and peptidoglycan transpeptidase (Fig. 6) when compared to other $\beta$-lactam antibiotics tested. Evidence that PBP $1 \mathrm{~b}$ may be one of the essential enzymes involved in cross-linking of peptidoglycan was presented by TAMAKI et $a^{10)}$. Our results show that, of the cephalosporins tested, the order of transpeptidase inhibition followed their affinities for PBP $1 \mathrm{~b}$ (Table 1 and Fig. 6).

\section{Acknowledgement}

We thank Mr. E. LASALA for MIC determinations and Mrs. B. TytLA for peptide analysis of UDP-MurNAc-pentapeptide.

\section{References}

1) Yoshikawa, T. T.; S. A. Shibata, P. Herbert \& P. A. Oill: In vitro activity of Ro 13-9904, cefaroxime, cefoxitin, and ampicillin against Neisseria gonorrhoeae. Antimicr. Agents \& Chemoth. 18: 355 356, 1980

2) Hinkle, A. M. \& G. P. Bodey: In vitro evaluation of Ro 13-9904. Antimicr. Agents \& Chemoth. 18: $574 \sim 578,1980$

3) Shelton, S.; J. D. Nelson \& G. H. McCracken, Jr.: In vitro susceptibility of Gram-negative bacilli from pediatric patients to moxalactam, cefotaxime, Ro 13-9904, and other cephalosporins. Antimicr. Agents \& Chemoth. 18: 476 479, 1980

4) Spratt, B. G.: Properties of the penicillin-binding proteins of Escherichia coli K12. Eur. J. Biochem. 72: $341 \sim 352,1977$

5) Makover, S. D.; R. B. Wright \& E. TeleP: Penicillin-binding proteins in Haemophilus influenzae. Antimicr. Agents \& Chemoth. 1981 (in press)

6) Spratt, B. G.; V. Jobanputra \& U. Schwarz: Mutants of Escherichia coli which lack a component of penicillin-binding protein 1 are viable. FEBS Lett. 79: 374 378, 1977

7) NozAKI, Y.; A. IMAdA \& M. YonedA: SCE-963, a new potent cephalosporin with affinity for penicillinbinding proteins 1 and 3 of Escherichia coli. Antimicr. Agents \& Chemoth. 15: 20 27, 1979

8) Moore, B. A.; S. Jevons \& K. W. Brammer: Peptidoglycan transpeptidase inhibition in Pseudomonas aeruginosa and Escherichia coli by penicillins and cephalosporins. Antimicr. Agents \& Chemoth. 15: 513 517,1979

9) Spratt, B. G.: Distinct penicillin binding proteins involved in the division, elongation and shape of Escherichia coli K12. Proc. Natl. Acad. Sci., U.S.A. 72: 2999 3003, 1975

10) Tamaki, S.; S. Nakajima \& M. Matsuhashi: Thermosensitive mutation in Escherichia coli simultaneously causing defects in penicillin-binding proteins $1 \mathrm{bs}$ and enzyme activity for peptidoglycan synthesis in vitro. Proc. Natl. Acad. Sci., U.S.A. 74: 5472 5476, 1977 